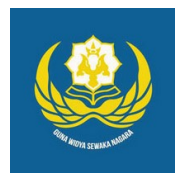

Jurnal Analogi Hukum

Journal Homepage: https://ejournal.warmadewa.ac.id/index.php/analogihukum

\title{
Kedudukan Cucu Sebagai Ahli Waris Pengganti Dalam Hukum Waris Islam (Studi Kasus Nomor: 0013/PDT.P/2015/ PA.DPS)
}

\author{
Ida Ayu Adi lin Yuliandari, I Ketut Sukadana dan Diah Gayatri Sudibya \\ Fakultas Hukum, Universitas Warmadewa, Denpasar, Bali-Indonesia \\ *ayuiinyuliandari@gmail.com
}

\begin{abstract}
How To Cite:
Yuliandari, I. A. A. I., Sukadana, I. K., \& Sudibya, D. G. (2020). Kedudukan Cucu Sebagai Ahli Waris Pengganti Dalam Hukum Waris Islam (Studi Kasus Nomor: 0013/PDT.P/2015/PA.DPS). Jurnal Analogi Hukum. 2(3). 346-350. Doi: https://doi.org/10.22225/ ah.2.3.2520.346-350
\end{abstract}

\begin{abstract}
Of all the current laws, inheritance law has a very important role and even determines and reflects the kinship system that has prevailed in that society. Lately there have been many disputes arising from the death of the heirs before the heirs. The case is sought out by forming a substitute heir concept. Legal issues regarding substitution of heirs are one of the concepts of renewal in the Compilation of Islamic Law. The concept of substitute heirs aiming to find a sense of justice for heirs. The formulation of the problem raised is (1) What is the position grandchildren as substitut heeirs in Inslamic intheritance law system according to the Compilation of Islamic Law, (2) How is the judge's judgment on the position of grandchildren as substitute heirs in the Determination of Denpasar Religious Court Number 0013/Pdt.P/2015/PA.Dps. In this research using normative legal research, namely in the study systematically process library materials and related decision files. In this study it can be concluded that the position of grandchildren as substitute heirs in the Islamic inheritance system according to the Compilation of Islamic Law based on the Determination of the Denpasar Religious Court Number 0013/Pdt./2015/PA.Dps that the grandchildren can replace the position of their parents as heirs, because based on Article 185 paragraph (1) Compilation of Islamic Law, a person can inherit because the replacement of the place is the person who is replaced musthave passed away earlier than the heir.
\end{abstract}

Keywords: Grandchildren; Substitute Heirs; Islamic Inheritance.

\begin{abstract}
Abstrak-Dari seluruh hukum yang berlaku saat ini, hukum kewarisan mempunyai peran yang begitu penting bahkan juga menentukan serta mencerminkan sistem kekeluargaan yang berlaku didalam masyarakat. Akhirakhir ini sangat banyak sengketa yang timbul akibat dari kasus permohonan ahli waris yang meninggal terlebih dahulu dari seorang pewaris tersebut. Kasus tersebut memiliki jalan keluar dengan dibentuknya sebuah konsep tentang ahliwaris pengganti. Permasalahan hukum tentang penggantian ahliwaris merupakan sebuah konsep yang diperbaharui dalam KHI. Konsep ahli waris pengganti bertujuan untuk memperoleh rasa keadilan bagi ahli waris. Adapun rumusan masalah yang diangkat adalah (1) Bagaimana kedudukan cucu sebagai ahliwaris pengganti didalam sistem kewarisan Islam menurut KHI? dan (2) Bagaimanakah perttimbangan majelis hakim terhadap kedudukan cucu sebagai ahliwaris pengganti didalam Permohonan Penetapan PA Denpasar Nomor: 0013/Pdt.p/2015/Pa.Dps.? Dalam penelitian ini menggunakan penelitian hukum normatif yaitu dalam pengkajiannya mengolah bahan-bahan kepustakaan serta berkas putusan yang berkaitan. Kesimpulan dari penelitian ini dapat dikatakan cucu yang berkedudukan sebagai ahli waris pengganti didalam sistem kewarisan Islam menurut KHI PA Denpasar mengeluarkan Penetapan Nomor: 0013/Pdt.p/2015/Pa.Dps bahwa cucu tersebut bisa menggantikan posisi kedua orang tuanya yang dapat disebut ahli waris, karena sesuai Psl 185 ayat $1 \mathrm{KHI}$, seseorang dikatakan bisa mendapatkan warisan karena memperoleh kedudukan yaitu seseorang yang telah diganti harus sudah dalam keadaan meninggal dunia lebih awal dari pada si pewaris .
\end{abstract}

Kata kunci: Cucu; Ahli Waris Pengganti; Waris Islam.

Jurnal Analogi Hukum, Volume 2, Nomor 3, 2020. CC-BY-SA 4.o License 


\section{Pendahuluan}

Dari keseluruhan hukkum yang telah berkembang serta yang berlaku sekarang disamping hukum perkawinan, hukum kewarisan adalah salah satu bagian diantara hukum kekeluargaan yang mempunyai peran penting, bahkan hukum kewarisan juga menentukan serta mencerminkan sistem kekeluargaan yang telah sesuai. Akibat ini timbul, karena hukumm waris islam sangatlah dekat kaitannya didalam ruang lingkup dari kehidupan. Di dunia, seluruh manusia akan mengalami peristiwa hukum yang disebut dengan meninggal dunia. Jika terdapat suatu kejadian hukum, tentang meninggalnya seseorang manusia akan mengakibatkan kejaadian hukum berupa pengurusan yang berkaitan tentang kelanjutan berbagai hak-hak maupun kewajiban orang yang sudah meninggal dunia. Penyelesaian pengurusan hakhak maupun kewajiban merupakan sebab dari timbulnya kejadian hukum tersebut karena sudah meninggal orang tersebut akan diatur didalam hukum warisan.

Dalam Hukum waris umat yang beragama Islam di Indonesia mempunyai konsep pembaharuan yaitu ditandai munculnya KHI dari INPRES RI No 1 Th 1991 pada Tgl 10 Juni 1991 tentang KHI. Setelah adanya Intruksi Presiden Republik Indonesia Nomor 1 Thn 1991 tntang Kompilasi Hukum Islam, seorang penegak hukum atau Majelis hakim tidak menggunakan lagi ajaran fiqh didalam memutus kasus yang dihadapi mereka,akan tetapi tetap digunakan KHI didalam petunjuk memutus suatu perkara, sekaligus memutus perkara waris.

Dalam beberapa literatur yang ada dalam hukum kewarisan Islam di Indonesia, permasalahan tentang penggantian ahliwaris merupakan terobosan baru tentang hukum kewarisaan Islam dalam KHI, yakni diberikannyaa hak seseorang ahliwaris yang telah meninggal terhadap penerusnya yang saat ini belum meninggal, seperti anak pewaris yang digantikan oleh cucunya. Aturan mengenai hal tersebut telah tercantum dalam ketentuan Pasal 185 Kompilasi Hukum Islam. Pasal 185 dapat mengangkat kedudukan seseorang yang awalnya tidak layak memperoleh harta waris, selanjutnya bisa diposisikan ke dalam kelompok ahli waris yang telah sudah mengalami kematian lebih terdahulu dari sipewaris. Namun di dalam psl itu belum dijelaskan bahwa dalam pasal tersebut sudah sesuai untuk ahliwaris yang memiliki garis keturunan kebawah, atau berlaku juga untuk ahliwaris yang memiliki garis kesamping, selain itu berlaku juga pada ahliwaris keatas.

Dalam kenyataannya, pemikiran mengenai sistem kewarisan Islam khususnya di Indonesia, terutama yang berhubungan di dalam sistem ahli waris pengganti, bersifat multi tafsir. Hal ini dimungkinkan terjadi, karena mengingat adanya pluralitas pemahaman hukum kewarisan diantara masyarakat muslim di Indonesia. Di dalam Hukum warisan untuk umat Islam di Indonesia dibagi atas beberapa paham tentang ajaran, yaitu menurut paham waris Ahlu sunah waljamaah, paham Syiah, paham Hazaiirin (Hasbiyallah, 2007).

Pada penelitian sebelumnya, (Kusmayanti \& Krisnayanti, 2019) Mengungkapkan Kedudukan cucu sebagai ahli waris pengganti dalam hukum waris Islam tidaktercantum dalam Al-Quran dan Hadist, hanya diakui melalui Ijtihad yangdilakukan para ulama. Namun dalam Kompilasi Hukum Islam keberadaan akancucu diakui sebagai penggantidari orang tuanya yang telah meninggal terlebihdahulu dari pewaris. Penelitian lainnya mengungkapkan penggolongan ahli waris, khususnya dalam sistem kewarisan Islam tidak dikenal adanya sistem pergantian tempat dalam pembagian kewarisan. Umumnya dalam khazanah kitab klasik, mereka lebih menyebut dengan istilah orang yang berhak menerima (furudul muqaddarah) karena sebab-sebab nasabiyah (keturunan) dan perkawinan.Sedangkan bagian yang diterima oleh ahli waris penggantitidak boleh lebih besar dari pada ahli waris yang diganti (Limbanadi, 2014).

Dari uraian latar belakang tersebut maka dapat diajukan dua rumusan masalah yang akan dibahas dalam penelitian ini yaitu kedudukan cucu sebagai ahli waris pengganti dalam sistem kewarisan Islam menurut Kompilasi Hukum Islam dan pertimbangan majelis hakim terhadap kedudukan cucu sebagai ahli waris pengganti dalam permohonan Penetapan PA Denpasar No 0013/Pdt.P/2015/PA.Dps

\section{Metode}

Tipe penelitian yang penulis gunakan yaitu Tipe Penelitian Hukum Normatif, yakni penelitian ini dilaksanakan yaitu dengan cara mengkaji serta menganalisis suatu peraturan perundang-undangan dengan isu hukum dalam konsistensinya terhadap asas-asas yang telah ada. Tipe pendekatan masalah yang digunakan dalam penelitian ini yaitu menggunakan pendekatan berdasarkan perundang-undangan (statue aproach), lalu menggunakan pendekatan berdasarkan kasus (case approach), serta 
menggunakan pendekatan berdasarkan

konsepttual (concepttual approach).

Dalam penelitian ini penulis menggunakan beberapa bahan hukum sebagai bahan penunjang dalam membuat penelitian ini yang mana diperoleh dari penelitian kepustakaan yaitu Sumber Bahan Hukum Primer yaitu, bahan hukm yang bersumber dari peraturan perundang-undangan yang terdiri dari: UU Peradilan Agama, UU Kekuasaan Kehakiman, Kompilasi Hukum Islam, Putusan Nomor 0013/ Pdt.P/2015/PA.Dps. Adapun Bahan hukum sekunder yang digunakan yaitu, berupa semua publikasi yang berkaitan mengenai hukum, seperti komentar atas putusan pengadilan. Bahan hukum sekunder itu harus menyangkut prinsip dasar ilmu hukum dan pandangan para ahli yang mempunyai kualifikasi tinggi.

\section{Hasil Penelitian Dan Pembahasan}

\section{Kedudukan Cucu Sebagai Ahli Waris Pengganti Dalam Sistem Kewarisan Islam Menurut Kompilasi Hukum Islam}

Di Negara Ini masalah tentang seorang cucu didalam memperoleh bagian harta waris dari seorang kakek akan diperoleh jalan keluar yaitu melalui dibentuknya sebuah objek ahliwaris pengganti. Objek ahliwaris pengganti itu diberi petunjuk dari seorang fuqaha (ahli hukum fiqih) dengan cara dirumuskannya kedalam KHI. Adanya keberlakuan objek tersebut dijelaskan untuk menyelesaikan suatu permasalahan dan untuk menghindari adanya persengketaan. Dalam ketentuan Al-Quran maupun Al-Hadits tidak ada petunjuk yang pasti. Hal ini lah Tuhan memberikan kepada umat manusia untuk ditentukannya hukum.

Pada dasarnya seorang yang menjadi ahli waris pengganti merupakan ahli waris karena penggantian tempat, yakni seseorang yang berhak menjadi ahli waris karena orang tuanya mendapatkan harta waris tersebut meninggal terlebih dahulu dari sipewaris sehingga posisi orang tua tersebut dapat diganti oleh anaknya. Dalam kenyataannya, pemikiran mengenai sistem kewarisan Islam di Indonesia, terutama yang berkaitan dengan sistem ahli waris pengganti, bersifat multi tafsir. Hal ini dimungkinkan terjadi, karena mengingat adanya pluralitas pemahaman hukum kewarisan diantara masyarakat muslim di Indonesia. Di dalam Hukum warisan untuk umat Islam di Indonesia dibagi atas beberapa paham tentang ajaran, yaitu menurut paham waris Ahlu sunah waljamaah, paham waris Syiah, dan paham waris Hazaiirin. Dari ketiga ajaran tersebut, pemikiran Hazairin yang cenderung bilateral lah yang dengan tegas mengemukakan esksistensi penggantian ahli waris (Hazaiirin, 1982). Aturan tentang ahli waris pengganti telah tercantum pada ketentuan Psl 185 KHI. Menurut Hazairin, hukum waris umat Islam tergambar dari dua pihak dan juga telah mengenal ahli waris pengganti.

Kedudukan cucu sebagai ahliwaris pengganti bisa mengganti kedudukan orangtua nya sebagai ahliwaris tetapi dalam konsep menggantikan, dimana seorang cucu bisa menggantikan posisi orangtua nya yang sudah meninggal dunia terlebih dahuluan biarpun pewaris memiliki anak laki-laki lainnya yang masihhidup. Seorang cucu itu tidak dibedabedakan apakah cucu itu laki-laki maupun wanita. Kedudukan seorang cucu posisinya tidak dibandingkan dengan kedudukan yang diperoleh dari anak sipewaris, yakni sehingga ahliwaris pengganti hanya saja mendapatkan pembagian harta warisan hanya dari pembagian warisan yang didapatkan oleh bapaknya. Kedudukan cucu ketika bapaknya meninggal terlebih dahulu dari pada kakeknya sudah tidak dipandang sebagai kerabat yang jauh.

\section{Pertimbangan Majelis Hakim Terhadap Kedudukan Cucu Sebagai Ahli Waris Pengganti dalam Permohonan Penetapan PA Denpasar No 0013/Pdt.P/2015/PA.Dps}

Timbulnya perkara perdata di pengadilan, diawali dengan diajukannya sebuah gugatan atau permohonan. Perkara perdata yang di dalamnya mengandung sengketa disebut dengan perkara gugatan (contentious), sedangkan perkara yang di dalamnya tidak mengandung sengketa disebut dengan perkara permohonan (voluntair) (Manan, 2012). Sesuai dengan permohonan Penetapan Ahli Waris Nomor 0013/Pdt.P/2015/PA.Dps, dalam kasus ini tersebut permohonan yangg diajukannya merupakan hak mewaris seorang ahliwaris berupa permohonan penetapan ahliwaris. Adapun ketentuan pokok tentang kewarisan dalam Islam tercantum di dalam ketentuan $\mathrm{Al}$ Quran Surat An-nissa ayat 11 dan ketentuan Al Quran Surat An-nissa ayat 12 yang ketentuan tersebut diterjemahkan di dalam aturan Kompilasi Hukum Islam yang telah tercantum didalam pasal 174

Hakim dalam menimang suatu putusan melambangkan unsur atau aspek yang penting, karena dalam sebuat keputusan tersebut dapat memberi kepastian dan rasa keadilan bagi para pemohon yang ingin mengajukan seusatu perkara ke pengadilan agar pihak yang 
berperkara dapat menerima keputusan tersebut.

Didalam surat Permohonan Penetapan PA Denpasar Nomor: 0013/Pdt.p/2015/Pa.Dps, seorang Majelis Hakim yang telah memeriksa memberikan pertimbangan dimana pada pokoknya sebagai berikut:

a. Menimbang, bahwa dalam persidangan Para Pemohon telah mengajukan bukti-bukti tertulis P.1 s/d P.12, bukti-bukti tertulis tersebut oleh Ketua Majelis telah dicocokkan dan sesuai dengan aslinya, oleh karenanya Majelis Hakim menilai bukti tertulis tersebut dapat diterima dan dapat dijadikan sebagai alat bukti yang sah;

b. Menimbang, bahwa dari fakta-fakta hukum, menurut Majelis Hakim telah terbukti bahwa Pemohon I (Kasim Darto) dan Supatmi adalah suami istri yang sah dan kemudian pada tanggal 17 Januari 2007 Supatmi telah meninggal dunia dengan meninggalkan ahli waris 4 orang anak yang masih hidup yaitu Sugeng Sugitor, Sukarmi Rahayu, Drg. Muslimin, Ahmad Suyono, sedangkan anak bernama Yusuf Sunyoto telah meninggal dunia lebih dahulu, namun ada mempunyai seorang anak perempuan bernama Dwi Nastiti Wiranjani;

c. Menimbang, bahwa bukti surat P.10 berupa Akta Kelahiran atas nama Dwi Nastiti Wiranjani adalah merupakan akta otentik yang mempunyai nilai pembuktian sempurna, sehingga terbukti Dwi Nastiti Wiranjani adalah anak dari alm. Yusuf Sunyoto bin Kasim Darto;

d. Menimbang, bahwa anak almarhumah yang bernama Yusuf Sunyoto sudah meninggal dunia terlebih dahulu daripada almarhumah, dimana kedudukan/posisinya bisa diganti oleh anak sipewaris yang bernama Dwi Nastiti Wiranjani sebagai ahli waris pengganti.

Majelis Hakim dalam perkara permohonan penetapan ahli waris, Nomor 0013/Pdt.P/2015/ PA.Dps mengabulkan permohonan para pemohon dengan salah satu diktum amarnya berbunyi

Menetapkan Para Pemohon yang bernama:

a. Kasim Darto Bin Sipoen (suami);

b. Sugeng Sugitor Bin Kasim Darto (anak lakilaki);

c. Sukarmi Rahayu Binti Kasim Darto (anak perempuan); d. Drg. Muslimin, SKG Bin Kasim Darto (anak laki-laki);

e. Ahmad Suyono, SE. Bin Kasim Darto (anak laki-laki);

f. Dwi Nastiti Wiranjani binti Yusuf Sunyoto (ahli waris pengganti);

Adalah ahli waris dari almarhumah (Supatmi binti Marhaban) yang berhak mengurus dan melakukan perbuatan hukum terhadap harta warisan dari almarhumah (Supatmi binti Marhaban) tersebut sesuai ketentuan hukum.

Pertimbangan hukum majelis hakim yang berkaitan dengan kedudukan cucu sebagai ahli waris pengganti, adalah majelis hakim dengan mendasarkan dalil permohonan Para Pemohon dan apa-apa yang telah diterangkan oleh para saksi Pemohon, menemukan fakta-fakta hukum telah meninggal dunia istri Pemohon I bernama Supatmi binti Marhaban pada tanggal 17 Januari 2007 karena sakit, serta telah meninggalkan ahliwaris yaitu beberapa anak (Para Pemohon) serta meninggalkan seorangcucu yang berjenis kelamin perempuan, dan juga meninggalkan harta peninggalan berupa dua bidang tanah sebagaimana SHM Nomor 1091 dan SHM Nomor 982.

Penyusun berpendapat, pertimbangan majelis hakim yang mengabulkan permohonan penetapan ahli waris, dengan mendudukkan cucu sebagai ahli waris pengganti tersebut, secara materiil telah tepat, karena majelis hakim telah menetapkan kedudukan ahli waris dari pewaris Supatmi binti Marhaban, dengan mendasarkan pada ketentuan Al-Qur'an yaitu dalam Surrat Annissa' ayat11 serta 12, psl 174 KHI, yakni pemohon I dalam kedudukan waris sebagai duda, Pemohon II hingga V dalam kedudukan waris sebagai anak laki-laki dan anak perempuan, ditambah seorang yang bernama Dwi Nastiti Wiranjani dalam kedudukan sebagai ahliwaris pengganti, dengan mengganti posisi waris sebagai anak seorang lakilaki karena ayah kandungnya tersebut meninggal lebih dahulu dari pewaris.

Akan tetapi secara formil, sebenarnya penetapan tersebut mengandung cacat, karena penetapan tersebut tidak didasari atas surat permohonan yang memenuhi kualitas formil, yakni berkaitan dengan tidak dimasukkannya cucu yang bernama Dwi Nastiti Wiranjani sebagai pihak dalam perkara, serta dalil permohonan tidak menguraikan secara rinci dan jelas tentang fakta yang menunjukkan hubungan hukum antara Dwi Nastiti Wiranjani 
sehingga ia menjadi ahli waris mengantikan Yusuf Sunyoto. Seharusnya atas keadaan cacat formil tersebut, majelis hakim menyatakan permohonan tersebut merupakan perkara yang pihaknya kurang (plurium litis consortium). Tetapi majelis hakim dalam mempertimbangkan cucu tersebut sebagai ahli waris pengganti didasarkan pada disebutkannya anak dari perkawinan antara almarhum Supatmi binti Marhaban dengan Kasim Darto bin Sipoen yang bernama Yusuf Sunyoto bin Kasim Darto di dalam posita, dan disebutkan bahwa memang benar Yusuf Sunyoto bin Kasim Darto meninggal lebih dulu dari pada ayahnya yang bernama Kasim Darto bin Sipoen, dan di dalam posita tercantum bahwa ia meninggalkan anak perempuan yang bernama Dwi Nastiti Wiranjani.

\section{Simpulan}

Kedudukan seorang cucu dalam konsep ahliwaris pengganti menurut ketentuan KHI, bahwa seorang cucu bisa mengganti kedudukan bapaknya sebagai ahliwaris tetapi dalam konsep penggantiann, dimana seorang cucu bisa menggantikan posisi bapaknya, dimana bapaknya tersebut meninggaldunia terlebih dulu biarpun sipewaris masih memiliki anak-anak yang lain yang masih hidup atau belum meninggal. Pada saat orangtua nya telah meninggal terlebih dahulu daripada kakeknya, seorang cucu tidak dipandang sebagaii kerabat dekat, karna cucu dikatakan sebagai garis keturunan lurus kebawah.

Pertimbangan Majelis Hakim terhadap kedudukan cucu sebagai ahliwaris pengganti didalam Permohonan Penetapan PA Denpasar Nomor 0013/Pdt.p/2015/Pa.Dps secara materiil telah benar pertimbangan majelis hakim yang mendudukkan cucu sebagai ahliwaris pengganti, tetapi oleh karena ada cacat dalam surat permohonan tersebut, maka seharusnya majelis hakim mempertimbangkan perkara tersebut adalah perkara yang pihaknya kurang serta gugatan yang dalilnya kabur / tidak jelas, majelis seharusnya menyatakan perkara tersebut tidak dapat diterima.
Kepada seluruh para ulama diharapkan agar mensosialisasikan tentang hukum kewarisan Islam yang berkaitan dengan ahliwaris pengganti melalui pengajian kemasyarakatan untuk mengatasi kendala didalam pelaksanaan hukum waris Islam. Kepada masyarakat khusunya yang beragama Islam, agar tidak terjadi permohonan Penetapan Ahli waris yang cacat, diharapkan dalam mengajukan surat permohonan Penetapan Ahli Waris ke Pengadilan Agama khususnya yang

berkaitan dengan penetapan ahli waris pengganti, identitas cucu tersebut dimasukkan ke dalam pihak pemohon.

\section{Daftar Pustaka}

Hasbiyallah. (2007). Cara Belajar Mudah Dalam Ilmu Waris. Bandung: Remaja Rosdakarya.

Hazaiirin. (1982). Hukum Kewarisan Bilateral Menurut Al-Quran dan Hadit's. Jakarta: Tintamas.

Kusmayanti, H., \& Krisnayanti, L. (2019). Hak Dan Kedudukan Cucu Sebagai Ahli Waris Pengganti Dalam Sistem Pembagian Waris Ditinjau Dari Hukum Waris Islam Dan Kompilasi Hukum Islam. Jurnal Ilmiah Islam FuturA, 19 (1), 68-85. Retrieved from https:// jurnal.ar-raniry.ac.id/index.php/ islamfutura/article/download/3506/3492

Limbanadi, A. (2014). Kedudukan Dan Bagian Ahli Waris Pengganti Dalam Hukum Islam. Lex et Societatis, 2(8), 170-180. Retrieved from https:// ejournal.unsrat.ac.id/index.php/ lexetsocietatis/article/view/6197

Manan, A. (2012). Penerapan Hukum Acara Perdata diLingkungan Peradilan Agama. Jakarta: Kencana Prenada Media Group. 